\title{
Újabb adatok a németlukafai üveghuta és keménycserépgyár történetéhez
}

\author{
EPERJESSY ERNŐ \\ H-1149 Budapest, Dongó u.14., e-mail: eperjessy.erno@gmail.hu
}

\begin{abstract}
EPERJESsy, E.: New data to the history of the Németlukafa tile manufacture and glasshouse.

Abstract: This paper complements the essay written by Eperjessy \& HORVATH (2013) on the history of the Németlukafa glasshouse. Besides two commemorative glass, a faience tobacco holder, two garden vases (kratér) made by Ignác Zsolnay in the Németlukafa glasshouse are described and a distribution map of the glasshouses in Zselic hills is published. The study insists on the importance of the high quality products and the role of the small manufactures.
\end{abstract}

Keywords: Zselic, Németlukafa, glass and tile manufacture, bath commemorative cups, faience vase made by Ignác Zsolnay

A Kaposvári Rippl-Rónai Múzeum Közleményei 2013. évi kötetében HoRvátH J. Gyula és EPERJESSY Ernő társszerzők tollából „Adatok a németlukafai üveghuta történetéhez" címmel jelent meg tanulmány (HoRVÁTH és EPERJESSY 2013). Jeleztük, hogy ebben HoRVÁTH J. Gyula elveszett kéziratának csak fennmaradt töredék anyagát állt módunkban közölni. Újabb, kiegészítő adatok felbukkanása várható volt. A cikk megjelenése után valóban újabb értékes adatok kerültek elő. Úgy véljük, hogy e szerénynek tudott kis „üveggyár”, illetve keménycserép manufaktúra teljesebb képéhez

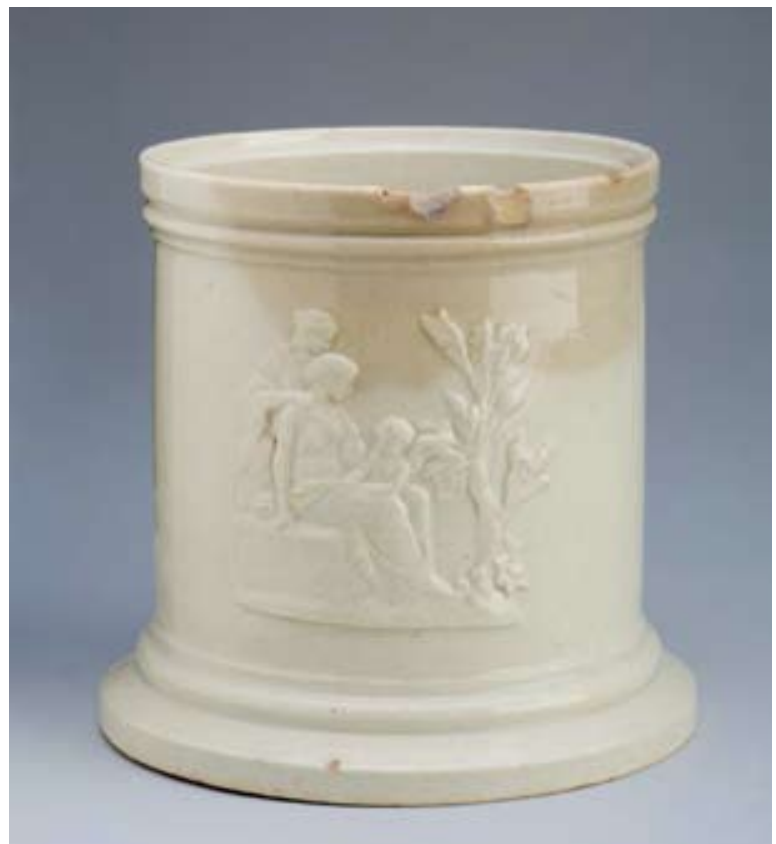

hozzátartozik, ha iparművészeti termékeinek jelentőségét újabb adatokkal bővítjük.

A korábbi tanulmányban szóltunk arról, hogy Pécsett 1948-ig létező „Lukafai üveggyári raktár” cégjelzéssel működő, elegáns üveg- és porcelánáru üzlet arra enged következtetni, hogy a lukafai manufaktúra üveges és keménycserép részlegében egyaránt, a 19. század polgári ízlésének megfelelő, magas iparművészeti igénnyel megjelent termékek is készültek. Ezt látszanak megerősíteni a „vaterán” (internetes régiségkereskedés) és az antikvár üzletekben napjainkban is fel-felbukkanó, akár ma is versenyképes fajansz és porcelánedények, aljukon kobaltkék színü „Lukafai üveggyári raktár" pecséttel.

A 2013-ban folytatott kutatás során derült ki, hogy a budapesti Iparmúvészeti Múzeum is őriz Lukafa jelzésü tárgyakat. Pontosabban két fajansz és két darab üveg talpas poharat. A fajanszok közül első helyen az un. „Dohány tartót” említjük, ami vásárlás útján 1944-ben került a múzeum birtokába. Vétel Fehér Istvánnétól, 301. - P. A kor és hely megjelölés szerint: "Lukafa, XIX. sz.e.d." (1. és 2. ábra).

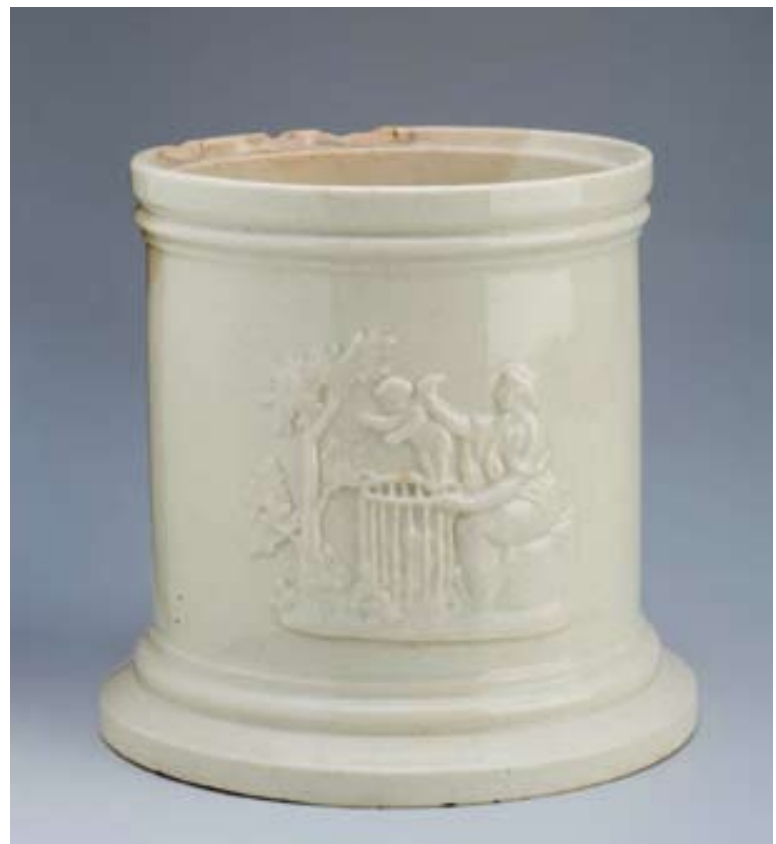

1. és 2. ábra: Dohány tartó. Keménycserép, vajszínü mázzal, oszlop alakú, tagolt-hengeres testén elől, egymásnak megfelelően 2 allegorikus dombormü ábrázolása. Az egyiken Vénusz kosárba teszi a szárnyánál fogva tartott kis Ámort, a másikon egy álló és egy ülö nőalak a kis szárnyas Ámorral. (Fedele hiányzik. Fenekén benyomva: LUKAFA 2. Magassága 13,5 cm, talpszélessége 14 cm. Lelt.sz: IM 19870.) (Fotó: Áment Gellért, 2013.) 
Következő tárgy ugyancsak az Iparművészi Múzeum anyagából való, szerényebb kivitelezésü fajansz tányér, amely feltehetöleg egy étkezési szerviz része (3. ábra).

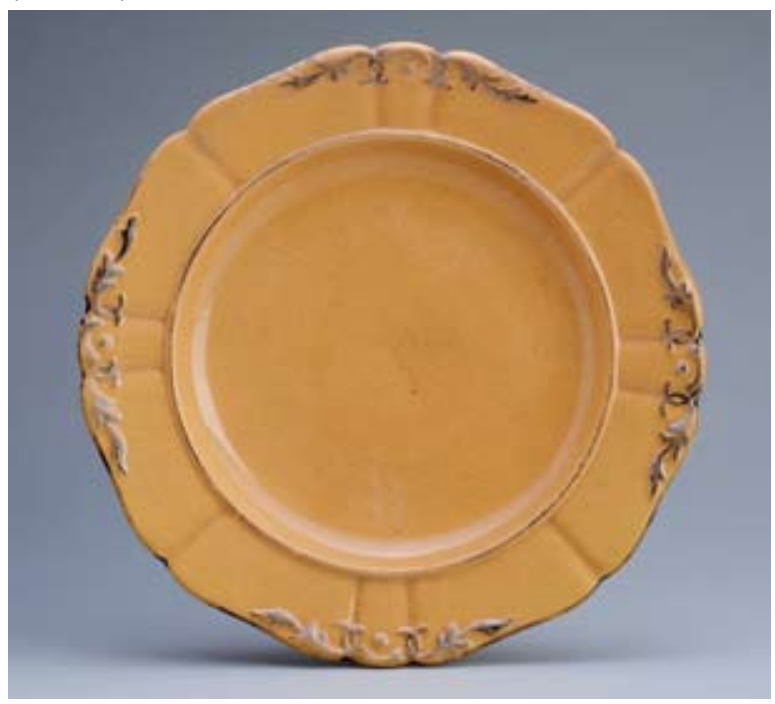

3. ábra: Tányér. Fajansz.(?) Lapos fenekü, pereme ivelt. Színe drapp, a fenék szélén ezüst csík, a perem szélén ezüst rocaille és levél díszítés. Keresztes Tiborné hagyatéka. Származás: Lukafa. (Átmérő 21,5 cm, magasság 3,2 cm. Lelt.sz: IM. 70.147.1.)

(Fotó: Áment Gellért, 2013.)

Amíg a fajansz és porcelán tárgyak esetében mélyített felirat vagy maradandó pecsét alapján könnyebb a származási helyet beazonosítani, az üvegtárgyak esetében ez bonyolultabb. Az üveg tárgyakon rendszerint készítési helyre és időre utaló jegyek nem találhatók. A csiszolt poharakon ritkán a megrendelő vagy a készítő monogramja fedezhető fel. Művészettörténész szakemberek csak bizonyos stílusjegyek alapján következtetnek gyártásuk helyére.

Az 1930-as években - a szerző által személyesen ismert -, az üveg- és porcelánkészítő munkások részben még fennálló, igénytelen házsorából következtetve, szinte hihetetlennek tűnik, hogy (Német-) Lukafán valamikor magas tudású iparművészek is dolgoztak. Bár ezt látszik sejtetni az előző számban már közölt míves üvegváza (HoRvÁTH és EPERJESSY 2013), amelynek festése mindenképpen gyakorlott müvészkézre vall. A minőségi termelésre utalnak a keménycserép részlegben készült, „Lukafai üveggyári raktár” pecséttel ellátott s már közölt színvonalas porcelánedények is (HORVÁTH és EPERJESSY 2013). Úgy véljük, hogy ennek további bizonyítéka az itt bemutatott fajansz dohánytartó, amelyen müvészi szintű mitológiai jelenetek láthatók.

„Európában már ismert nagyobb fürdőhelyek szokásaihoz hasonlóan, a XIX. század középső évtizedeitől Magyarországon is megjelentek az ivókúra poharak. Az üvegtestek díszítő színezése legtöbbször bíborvörös pácolással történt, de gyakoriak a színtelen poharak is. ... megjelenésük az 1840-es évektől történhetett." - olvasható NÉMETH Lászlótól a Balatonfüred poharairól írt tanulmányában ${ }^{1}$. Az üvegmủvészettel foglalkozó kutatók nyomán azt is bizonysággal feltételezhetjük, hogy a XIX. sz. közepétől az üzem bezárásáig (1887, mások szerint 1894), Lukafán is készültek múvészi színvonalú üvegtárgyak a korabeli polgári ízlésnek megfelelően. E vonatkozásban, első ízben Borsos Béla kiváló művészettörténész, az üvegművesség nemzetközi rangú ismerője tesz említést arról, hogy a XIX. században divatba jött hírneves fürdőhelyek emlékpoharainak („fürdős pohár”, „fördős pohár") egyik gyártója többek közt Lukafa lehet (BoRsos 1965,1977$)^{2}$. Ebben a témakörben ugyancsak NÉMETH László tesz említést Lukafáról, amikor Balaton-Füred fürdő ivókúra poharairól ír. „A füredi poharak alakja igen változó, több darab összehasonlításával sem található azonos forma. Feltételezhető, hogy a poharakat különböző helyről szállították, készítői nem ismertek. Elsősorban magyar hutákra kell gondolnunk, mint például Bártfa, Parád, esetleg Lukafa, de stílus alapján cseh vagy osztrák beszerzés is lehetséges." 3 VARGHA Vera már részletesen is bemutat egy rubinszínü pácolással készült, míves, talpas díszpoharat (VARGHA 1989), amelyről bizonyossággal tudjuk, hogy 1855ben Lukafán készült. Erről többek közt a következőket írja: „E talpas díszpohár... 1855-ben a lukafai hutában készült, vésett díszítése Stanek Vince munkája. Készitési helyéröl a lukafai, teljes nevén németlukafai üvegcsürröl viszonylag keveset tudunk, annyi bizonyos, hogy 1800-ban létesült, s Lukafa ettöl kezdve vált komolyabb településsé. A huta egyes adatok szerint már 1888-ban, mások szerint röviddel 1894 elött szüntette be müködését. Az itt dolgozó üvegesek létszáma - az ekkor müködő kisebb magyar, általában inkább csak helyi igényeket kielégítő hutákra jellemzően - öt és tizenkét fö között váltakozott... A Stanek (Sztanek) család is ebben a kezdeti időszakban került Lukafára $s$ a dinasztia tagjai egészen a huta bezárásáig dolgoztak itt. - Stanek Vince mestermunkája ... kristályüveg alapanyagú, karéjolt talpú, hat lapra facettált talpas pohár ..., amelyen a cupparész első három lapját ... medalionba komponált, vésett „három párka” ábrázolás tölt ki. A medalion felső részén körben, frízszerüen elrendezett gót betüs felirat olvasható: 'Spinnet noch lange den Faden des Lebens.' (Sorsasszonyok fonják még hosszúra életed fonalát.)... A cupparész három hátsó lapján kisebb medalionokban „S” „W" monogram és „8. Septbr. 1855.” felirat. ... A tárgy formaadása és díszítésmódja igen magas müvészi szintü, megmunkálása a német üvegmüvesség legjobb hagyományainak átörökítését mutatja.” ${ }^{4}$ (4. és 5 . ábra)

1 Németh László: Balaton-Füred fürdő ivókúra poharai. In: Füredi Históra (helytörténeti folyóirat), VII. évf. 2. szám. 7. p. Balatonfüred - Zánka 2007.

2 Borsos Béla: (Építész, művészettörténész, hosszú ideig a Műemlék Felügyelőség osztályvezetője, az üvegmüvesség nemzetközi rangú kutatója.) Régi magyar üvegmüvészet, 1965; A magyar üvegmüvesség, 1977.

3 Németh László: u.a.

4 Vargha Vera: Régi magyar üveg. Iparművészeti Kiadó, 1989. 3435. p. 

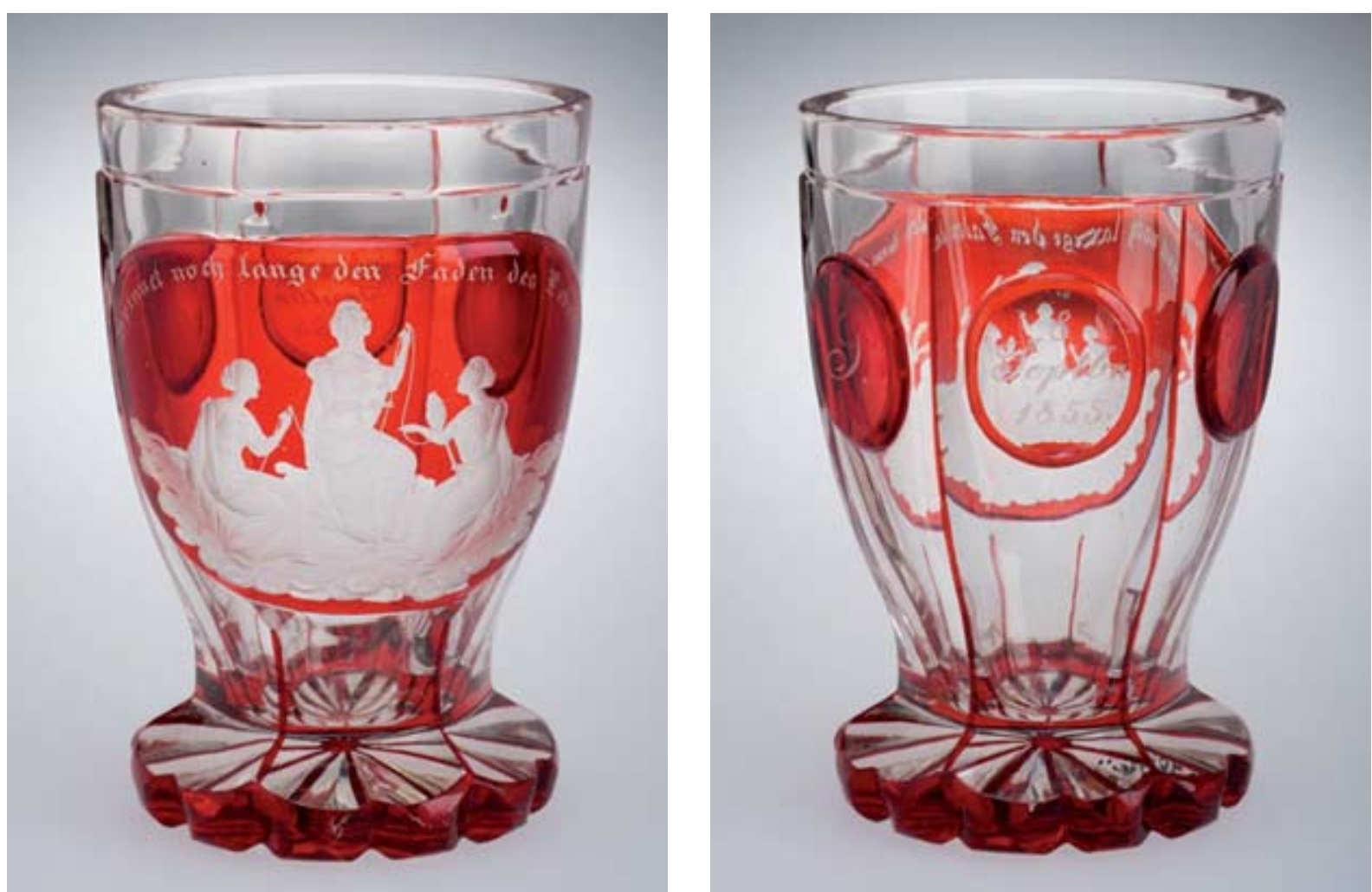

4. és 5. ábra: Fúvott, rézrubinpácolt üveg. Tizenkét karéjolt talpból kinövő, testén elöl vörös fekvő oválisban a három párka alakja köszörülve, fölötte „Spinnet noch lange den Faden des Lebens.”, hátoldalán vörös oválisban S.W. közepén „8. Septbr. 1855”. Mindez köszörülve, sima ajakperem, talpa széle vörös. Az eladó közlése szerint dédapja Stanek Vince készítette felesége számára Lukafán. (Vétel: Törvényi László, 1956. Vételár: 250 Ft. Méret: $12.4 \mathrm{~cm}$ magasság, 7-2 cm átmérő. Lelt.sz: IM.56.406.1) (Fotó: Áment Gellért, 2013.)

VARGHA Vera - mint egyidőben az Iparmüvészeti Múzeum munkatársa is - ugyanebben a müvében egy másik „fürdős poharat” is bemutat, amely - sajátságos jegyei alapján - szintén a lukafai üveghuta termékének tulajdonítható. Ez festőtechnikával, un."schwartzlot" stílusban készült. E díszítési módot föleg osztrák, illetve cseh cégek alkalmazták magas szinten. A remek díszpohár aranyozása erősen kopott, festett képe azonban teljesen ép. A szerző - a már említett munkájában - így ír róla: „E magyar tárgy viszont a XIX. századi emlékpoharak tipikus formájú példányán..., aranyozott keretelésü, lesarkitott téglalap alakú medalionban, két épület látható tájháttér előtt - Kávéház és új Fürdő Harkányba - felirattal." ${ }^{5}$ Az ábrázoláson a XIX. századi Harkány egy hiteles részlete látható. ${ }^{6}$ (6. ábra)

5 Vargha Vera: u.a.

$6 \mathrm{Az}$ emeletes épület a háború után mozi és cukrászda lett, az 1950-es években lebontották. A mögötte látható kis gloriett alatt „A három párka.” c. terakotta szobor állt, alapzatából iható harkányi ásványvíz csordogált. A háború után a gloriett elpusztult, a terakotta szobor az 1950-es években tűnt el. A mögötte ábrázolt „új Fürdő” Kosssuth-fürdő címen több mint 100 évig szolgálta a betegek gyógyulását. Az ovális alakú épületet, fából készült oszlopos tornác keretezte. Az 1970-es években, a müemléknek számító épület, „korszerülensége” miatt került lebontásra.(Eperjessy Ernő)
A következők a Zsolnay-gyárral kapcsolatosak. A bemutatott két kratér (kerti talpas virágtartó) egyes feltételezések szerint Lukafán készült fajanszáru. Készítője, a Zsolnay-gyár első tulajdonosa Zsolnay lgnác lenne, akiről tudjuk, hogy egy éven át, Lukafán tanulta ki a mesterséget. ZsolnAY Teréz és M. ZsoLNAY Margit (1974) kötetében olvashatjuk: „Ignác egy évet töltött Lukafán, hogy megtanulja az agyagáruk gyártását." A lukafai üzem minőségi termelésére ugyancsak ZsolnAY Teréz utalása alapján következtethetünk, miszerint „... a Littke-család birtokában van két kratér alakú talpas váza, amelyeket lgnác még Lukafán készített." ${ }^{\circ}$ Ugyancsak itt olvasható, hogy Ignác a pécsi üzem szervezése során úgy véli, „... ugyanolyan szép edényt_fogok készíteni, mint amilyent Lukafán állitottam elö." ${ }^{9}$ HoRvÁTH J. Gyula hátrahagyott jegyzeteiben tudni véli azt is, hogy Ignác által Lukafán készített két díszes kratér, „... a Littkey-pezsgőgyár államosítása után kerültek múzeumi tulajdonba. A Zsolnay Múzeum belső udvarában a mai napig láthatók." ${ }^{10} \mathrm{Ha}$ elfogad-

$7 \quad$ Zsolnay Teréz - M. Zsolnay Margit: Zsolnay. A gyár és a család története, 1863-1948. Corvina Kiadó. Gyoma, 1974. 10-12. p.

8 Zsolnay Teréz - M. Zsolnay Margit: u.a. 10-12. p.

9 Zsolnay Teréz - M. Zsolnay Margit: u.a. 10-12. p.

10 Horváth J. Gyula (1918 - 2013.) Almamellék, Ibafa, Mozsgó plébánosa, a németlukafai üveghuta 50 éven át tartó kutatója, halálakor kézirata elveszett. Az idézett szöveg a hagyatékban maradt jegyzeteiben szerepel. 


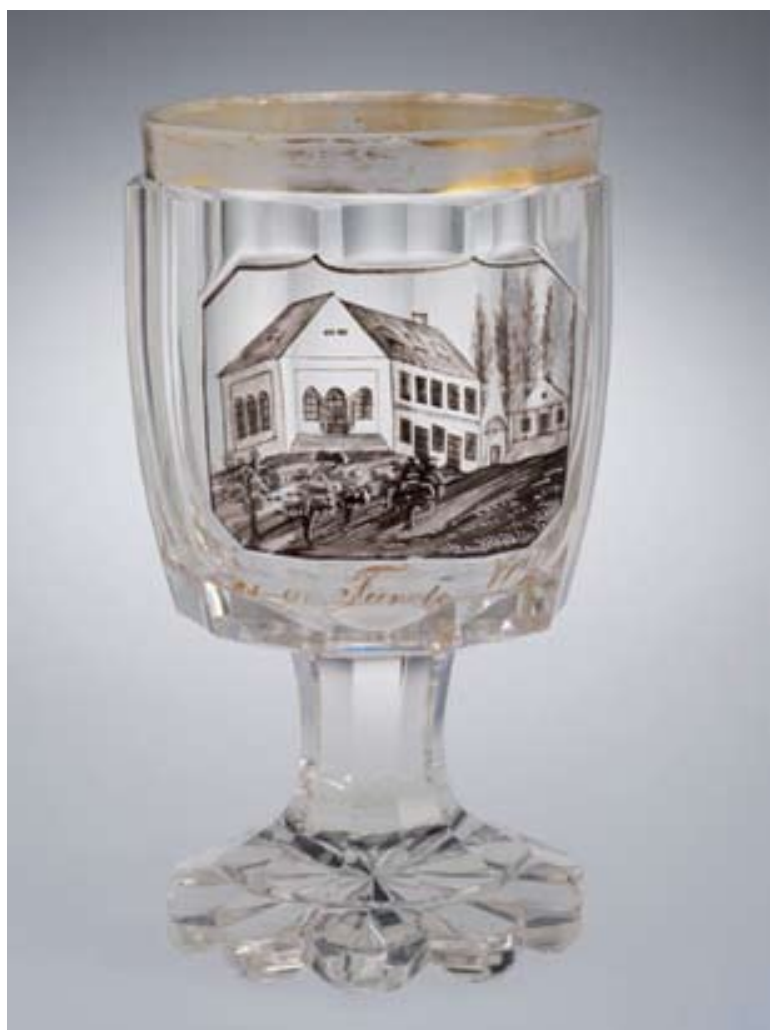

6. ábra: Fördőpohár. Színtelen üveg, tagolt talpa 10 karéjos, ... oldalt 10 lapra hámozott... Elöl levágott sarkú fekvő téglalapban fák között álló emeletes épület, alatta felirat arannyal: Kávéház és új Fürdő Harkányba. Lukafa /?/ 1860-1870 k. (Vétel, BÁV 118.- Ft, 1958. Lelt.sz: IM. 58.1056.1) (Fotó: Áment Gellért, 2013.) juk a vitatott két kékszínű kratér lukafai eredetét, csak megerősíti, hogy a kis lukafai üzemben magas színvonalú termékek is készültek. (7. és 8 . ábra.)

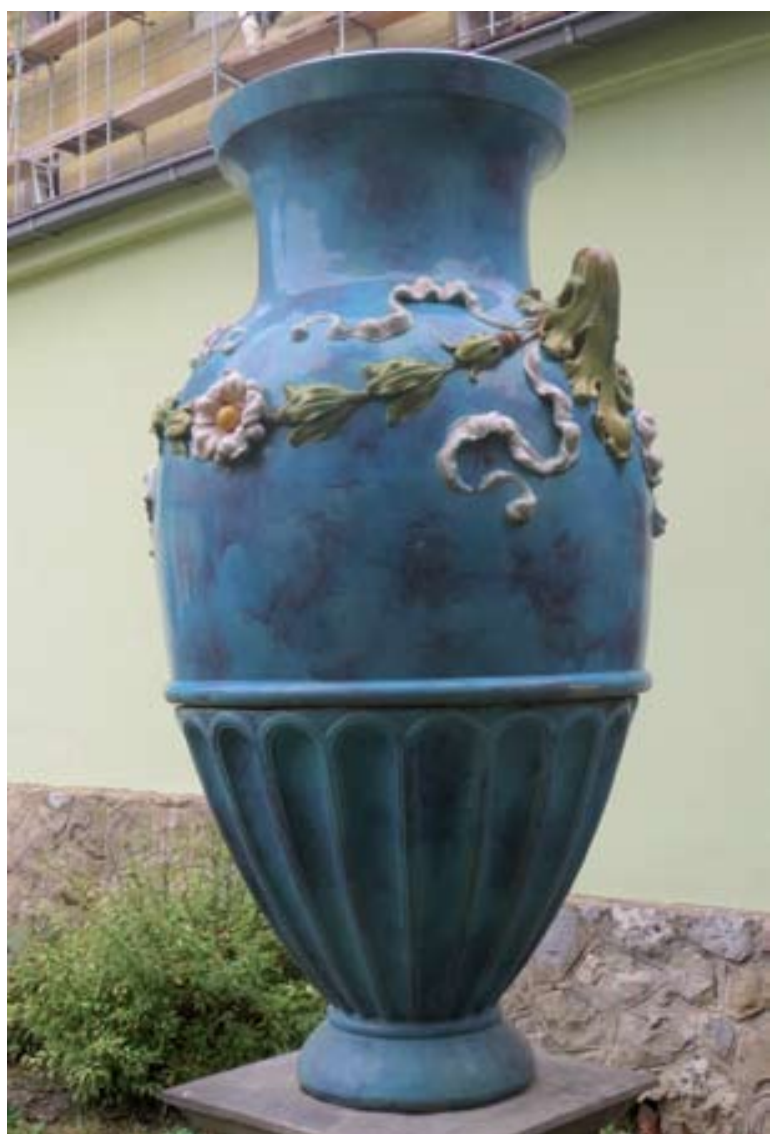

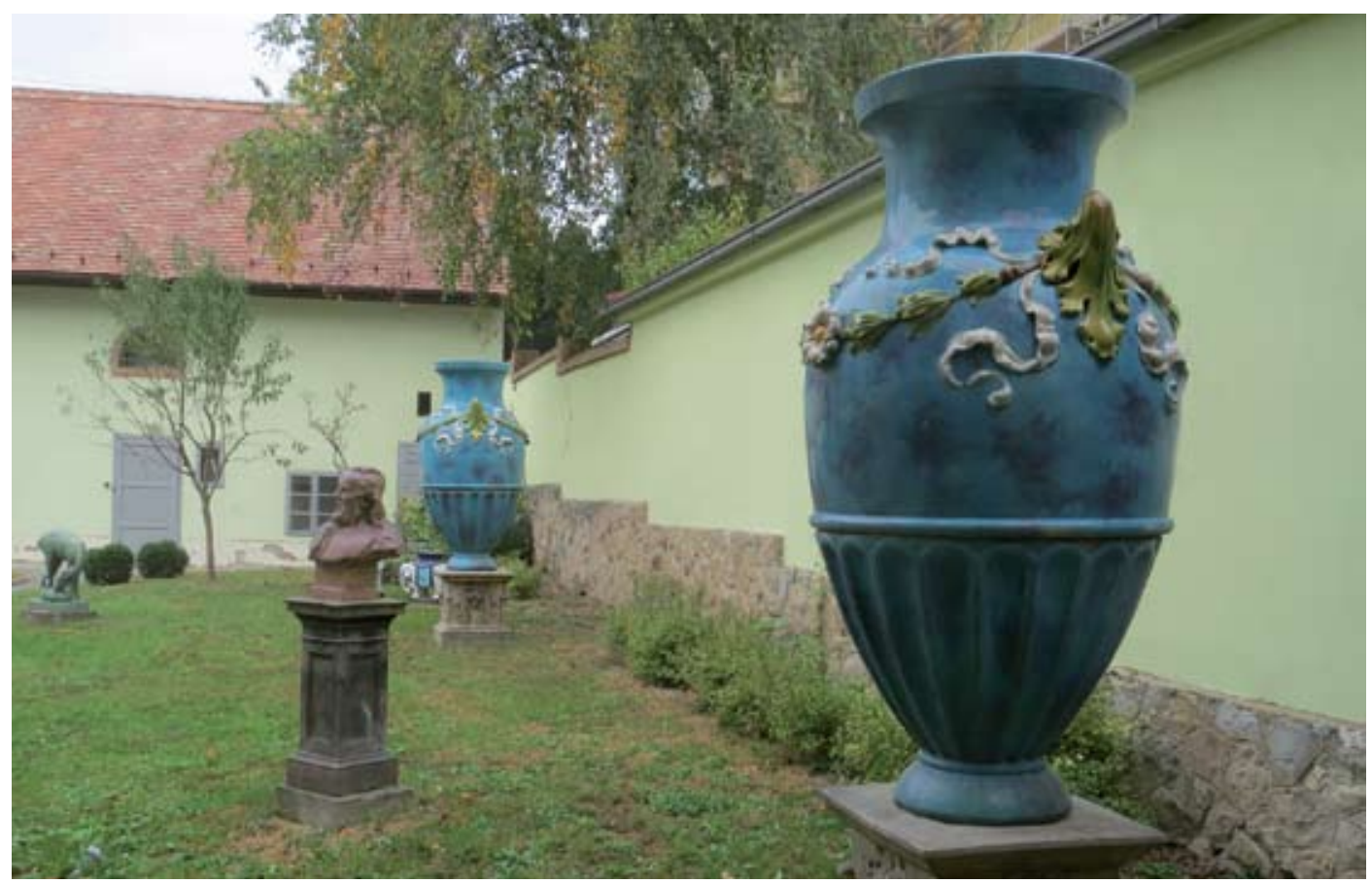

7. és 8. ábra: Egyes szakírók szerint Zsolnay lgnác által Lukafán készített, a pécsi Zsolnay Múzeum belső udvarában ma is látható, kék színü kerti vázák (kratér). (Fotó: Frankovics György, 2014.) 


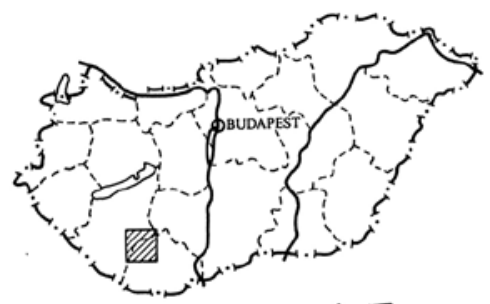

\section{A ZSELICI ÜVEGHUTÁK XVIII-XIX. század}

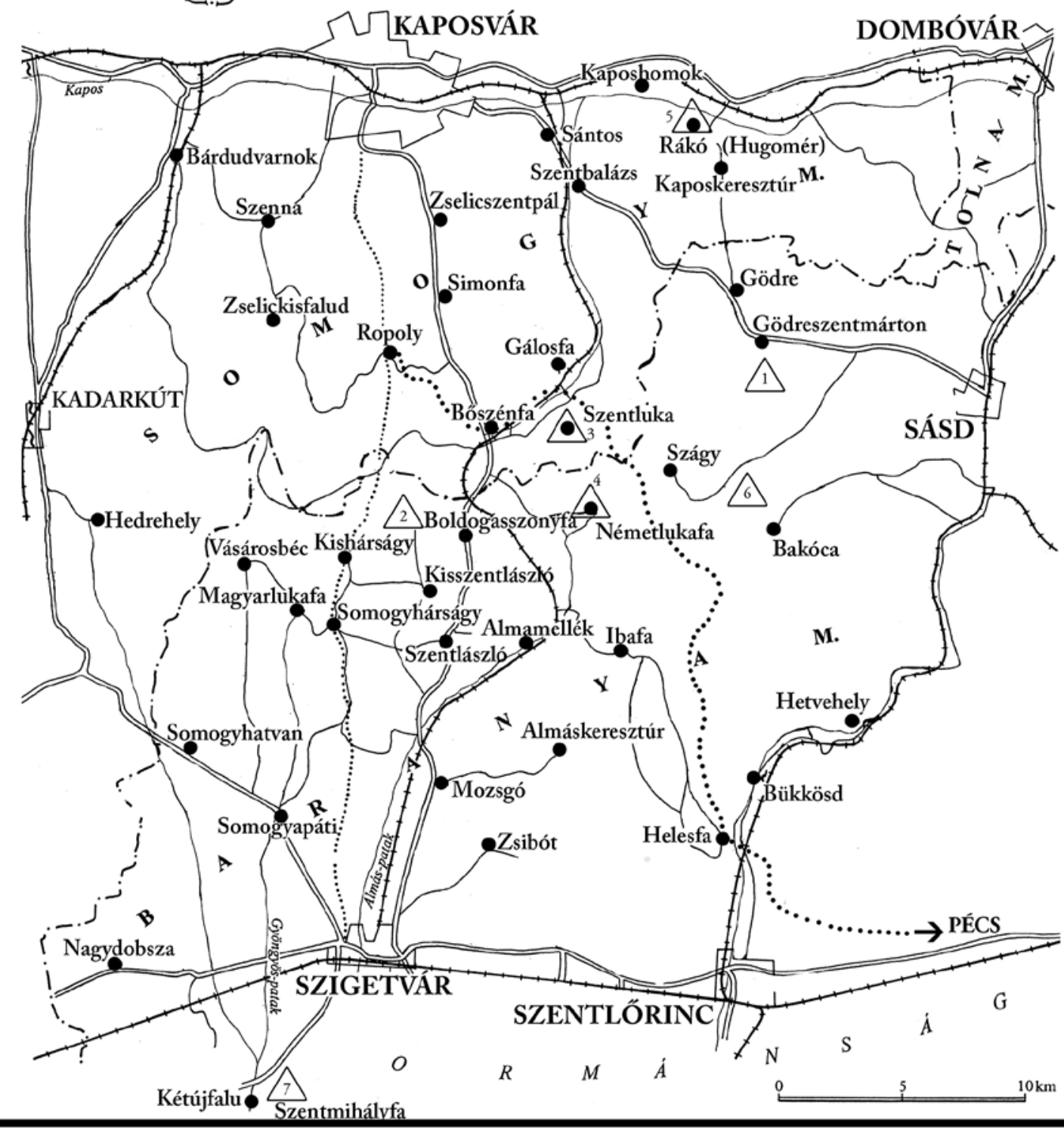

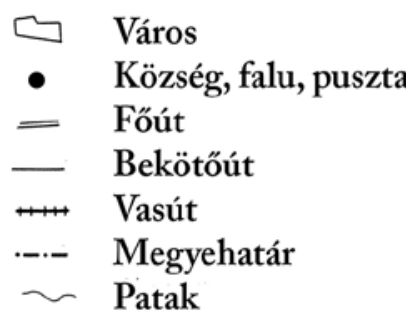

A Hárságyi-derékút (Betyárok útja)

XVIII - XIX. sz. Kaposvárt

Péccsel összekötő földút
Üveghuták:

1. Gödreszentmárton

2. Somogyhárságy

3. Szentluka

4. Németlukafa

5. Hugomér (Rákó)

6. Bakóca

7. Szentmihályfa 
A felbukkanó újabb adatok kedvéért LICHTNECKERT András egy 2013-ban megjelent írására (LICHNECKERT 2013) szeretnénk utalni. Az ebben közölt adatok Lukafa üvegtermelési kapacitására is engednek következtetni. Ugyanis a füredi kút savanyúvizét kb. az 1800-as évek elejétől, mint gyógyvizet palackozva, országosan is forgalmazták. A szerző a Veszprém Megyei Levéltárban található, Balatonfüred gazdasági számadási adatai alapján, többek közt részletes kimutatásokat is közöl a palackozáshoz használt üvegek beszerzési helyéről, idejéről, beszerzési áráról. Ezek szerint a palackozáshoz szükséges üvegek egyik szállítója a Kaposvári Spitzer-cég lukafai üveggyára volt. „Écsy László fürdőfelügyelő 1865-ig az üvegeket 3 forrásból szerezte be, a Spitzer-féle kaposvári (lukafai), a Karger-féle vétyemi (ma Tormafölde) és a somhegyi (ma Bakonybél) üveghutából Preisach Henrik veszprémi kereskedőn keresztül. 1840-1842 között és 1855-ben Spitzertöl 59,1 ezer, 1843-1854 között Preisach Henriktöl 171,8 ezer, 1851-1854 között Karger Alajostól 38 ezer palackot szállitottak Füredre."11 A Savanyúvíz felügyelői számadásokban szereplö részletesebb adatok szerint, a használatos üvegek szállítása Spitzer Mór lukafai üzeméből 1840 és 1873 között a következők szerint alakult: „1840 - 22 231; 1842 - 9 914; 1855 - 27 013; 1856 - 14 485; 1857 -

11 Lichtneckert András: $A$ balatonfüredi savanyúvízi gyógyfürdő története az alapítástól az államosításig.1702 - 1949. 121.p. Balatonfüred, 2013.
18 053; 1858 - 17 056; 1859 - $14414 ; 1860$ - 14415 ; 1861 - 13 916,1862; 1862 - 14 579; 1863 - 13 808; 1864 - 11 443; 1873 - 9312 db. ... A kaposvári és a lukafai üveghuta ugyanazt a Spitzer-féle üveghutát jelentette."12 LICHTNECKERT Andrástól és NÉMETH Lászlótól tudjuk, hogy az üvegpalackokat később kiszorítják a kevésbé törékeny, Rajna menti Hessen tartományból származó (körpecsétjeik alapján: Selters Nassau), úgynevezett német kőcserép korsók. NÉmETH László (2014) tanulmányában írja: „... a forgalmazás részben üveg, majd az úgynevezett seltersi kőedény korsókban, palackokban történt." ${ }^{13}$. Feltehetően a füredi megrendelések elmaradása gazdaságilag a lukafai üveggyár termelését is erősen érintette.

A 2013-ban megjelent tanulmány (HoRVÁTH és EPERJESSY 2013) után több szakmai érdeklődő jelezte, hogy a zselici üveghutákról kutatói tájékozódás okán, hasznos lenne egy topográfiai vázlat közlése. A felvetés alapján a hiányt jelen tanulmányban egy földrajzi vázlattal (9. ábra) kívánjuk pótolni.

12 Lichtneckert András: ua. 422-423.p.

13 Németh László: A balatonfüredi Selters gyógyvizes korsók kérdéséhez. In: Füredi História (Helytörténeti folyóirat.) XIV. évf. 3. sz. 3. p. Balatonfüred - Veszprém, 2014.

\section{Irodalom}

Borsos B. 1965: Régi magyar üvegművészet. - Budapest.

Borsos B. 1977: A magyar üvegmüvesség. - Budapest.

HorvÁth J. Gy. és EPERJessy E. 2013: Adatok a németlukafai üveghuta történetéhez. - A Kaposvári Rippl-Rónai Múzeum Közleményei 1: 235-250.

LICHNECKERT A. 2013: A balatonfüredi savanyúvízi gyógyfürdő története az alapítástól az államosításig. - Balatonfüred.
NÉMETH L. 2014: A balatonfüredi Selters gyógyvizes korsók kérdéséhez. - Füredi História (helytörténeti folyóirat) XIX. évf. 3. sz., Balatonfüred - Veszprém.

VARGHA V. 1989: Régi magyar üveg. - Iparművészeti Kiadó, Budapest.

Zsolnay T. és M. Zsolnay M. 1974: Zsolnay. A gyár és a család története, 1863-1948. - Corvina Kiadó, Gyoma. 